\title{
Isolation and characterization of microsatellite loci in the black pepper, Piper nigrum L. (piperaceae)
}

\author{
I. C. Menezes $\cdot$ F. W. Cidade $\cdot$ A. P. Souza $\cdot$ \\ I. C. Sampaio
}

Received: 19 June 2009/ Accepted: 25 June 2009/Published online: 8 July 2009

(C) Springer Science+Business Media B.V. 2009

\begin{abstract}
The black pepper, Piper nigrum L., which originated in Índia, is the World's most important commercial spice. Brazil has a germplasm collection of this species preserved at the Brazilian Agricultural Research Corporation (Embrapa-Eastern Amazonia) where efforts are being made to generation information on the patterns of genetic variation and develop strategies for conservation and management of black pepper. Molecular markers of the SSR type are powerful tools for the description of material preserved in genetic resources banks, due to characteristics such as high levels of polymorphism, codominance and Mendelian segregation. Given this, we developed nine microsatellite markers from an enriched library of Piper nigrum L. Twenty varieties clonal from the Brazilian germplasm collection were analyzed, and observed and expected heterozygosity values ranged over $0.11-1.00$ and $0.47-0.87$, respectively. The nine microsatellite loci characterized here will contribute to studies of genetic diversity and conservation of Piper nigrum $\mathrm{L}$.
\end{abstract}

Keywords Microsatellites - Piper - Spices . Genetic diversity

I. C. Menezes ( $\square)$

Empresa Brasileira de Pesquisa Agropecuária (Embrapa)-

Amazônia Oriental, Belém, PA CEP 66.095-100, Brazil

e-mail: ilmarina@cpatu.embrapa.br

F. W. Cidade · A. P. Souza

Centro de Biologia Molecular e Engenharia Genética, Departamento de Genética e Evolução, Universidade Estadual de Campinas, CP 6010, Barão Geraldo, Campinas, SP CEP 13.083-970, Brazil

I. C. Sampaio

Instituto de Estudos Costeiros (IECOS), Universidade Federal do Pará, Bragança, PA CEP 68.600-000, Brazil
The genus Piper, the largest of the Piperaceae family, has its species distributed through all continents of both Old and New world with several forms of growth, from herbs, small trees, even lianas, forming about 2,000 species. About four hundred (400) of them are found in Brazil, including 300 in the Amazon region alone (Jaramillo and Manos 2001; Quijano-Abril et al. 2006). The family includes several economically important species like black pepper, Piper nigrum L., a tropical woody perennial, the spice most consumed worldwide (Albuquerque et al. 2001). The specie is an autogamous plant with a small percentage of cross pollination, vegetative propagation, despite its fertile seeds (Nair et al. 1993; Johnson et al. 2005). There are more than 75 black pepper cultivars in Índia of natural and cultivated occurrences and morphological characteristics of the accessions in the collection are being recorded systematically (Nambiar et al. 1978; Johnson et al. 2005).

Informative molecular markers, with a high degree of polymorphism, codominants, and Mendelian inheritanceall characteristics presented by microsatellites-are important for the evaluation of the variability existing in germplasm collections, providing a better focus for conservation efforts, and generating guidelines for the development of cultivar improvement programs (Souza 2001). The evaluation of genetic variability in germplasm depends on neutral and polymorphic markers regarding environmental effect, and the SSR which is characterized for occurring, most of the time, in extragenic locations thus enabling this effect. The isolation and characterization of microsatellites from an enriched library for Piper nigrum L. are described in the present study.

Genomic DNA was isolated from the leaves of a specimen of the Singapore cultivar using the CTAB (Cetyltrimethyl Ammonium Bromide) method developed by Doyle and Doyle (1990). An enriched library was 


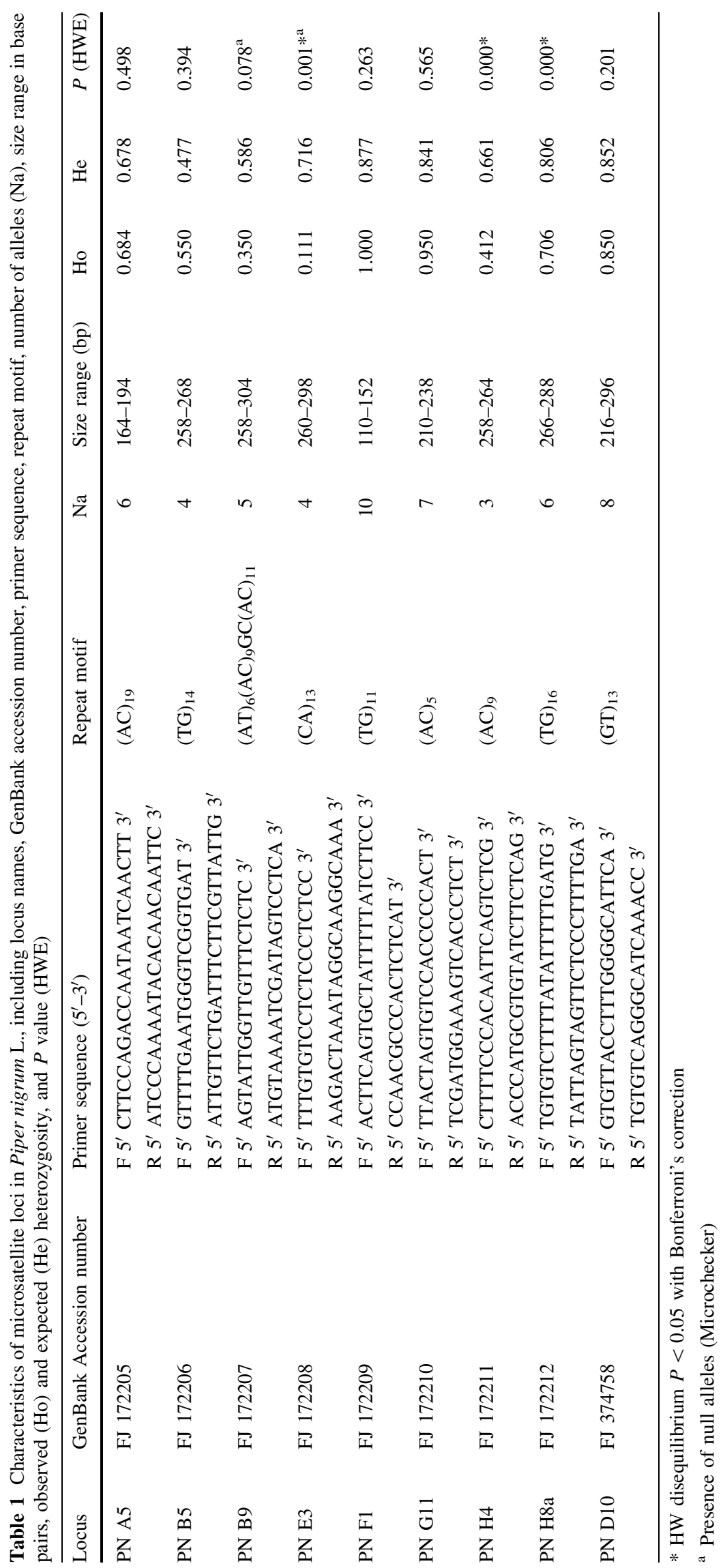


Table 2 Results of the tests in four different Piper species for the microsatellites isolated in Piper nigrum L.

\begin{tabular}{llllllllll}
\hline Espécies & PN A5 & PN B5 & PN B9 & PN E3 & PN F1 & PN G11 & PN H4 & PN H8a & PN D10 \\
\hline P. attenuatum & - & + & - & + & - & + & & + & + \\
P. hispidinervium & - & + & - & + & - & + & + & + & + \\
P. tuberculatum & - & + & - & + & - & + & + & + & + \\
P. colubrinum & - & + & - & + & - & + & + & - \\
\hline
\end{tabular}

Successful amplification (+) and failed amplification (-)

constructed using the method described by Billotte et al. (1999). The genomic DNA was digested with RSA I, the fragments were linked to adaptors and enriched with the biotinylated probes $(\mathrm{CT})_{8}$ and $(\mathrm{GT})_{8}$. The selected fragments were then amplified by Polymerase Chain Reaction (PCR), and the product cloned in a pGEM T-Easy vector (Promega) before being transformed in competent $E$. coli (XL1-blue), using the expression of the $\beta$-galactosidase gene for the identification of positive clones, which were grown and stored in 2YT HMFM culture medium with ampicillin. Following plasmidial extraction and PCR, 192 clones were sequenced in an ABI PRISM 377 using the primers T7 and SP6. Repetitive regions were identified using the Simple Sequence Repeat Identification Tool (Temnykh et al. 2001) and 57 clones were positive for microsatellites. The sequences were edited and aligned using the SeqMan (DNAstar Inc.) program. Thirty-six of the clones containing microsatellites in appropriate regions were used to design the primers in the regions that flank the repetitions using the programs Primer Select (DNAStar) and Primer3 Plus (Rozen and Skaletsky 2000).

For analysis of genetic variability of the microsatellites, 20 varieties clonal of Piper nigrum $\mathrm{L}$. were obtained from the germplasm collection of the Brazilian Agricultural Research Corporation (Embrapa-Eastern Amazonia). Amplification by PCR was conducted in a final reaction volume of $25 \mu \mathrm{l}$ containing 1X PCR Buffer, $1.5 \mathrm{mM} \mathrm{MgCl} 2,0.15 \mathrm{mM}$ of each dNTP (Fermentas), $0.2 \mu \mathrm{M}$ of each primer, $1 \mathrm{U}$ of Taq DNA polymerase (Invitrogen) and $20 \mathrm{ng}$ of genomic DNA. A PTC-200 (MJ Research) model thermocycler was used to conduct a protocol that consisted of an initial cycle of $1 \mathrm{~min}$ at $94^{\circ} \mathrm{C}$ for denaturation, 30 cycles of $1 \mathrm{~min}$ at $94^{\circ} \mathrm{C}$ for denaturation, $1 \mathrm{~min}$ at $58^{\circ} \mathrm{C}, 1 \mathrm{~min}$ at $72^{\circ} \mathrm{C}$ and a final period of extension at $72^{\circ} \mathrm{C}$ for $5 \mathrm{~min}$. The products of the amplification were separated in polyacrylamide denaturing gel and colored with silver nitrate, as described by Creste and Tulmann Neto (2001). Allele size was estimated using a $10 \mathrm{bp}$ Ladder (Invitrogen).

The number of alleles, observed and expected heterozygosity, and the test for Hardy-Weinberg equilibrium (HWE) were calculated using the program Tool for Genetic Population Analysis-TFPGA (Miller 1997). The number of alleles per locus varied from 3 to 10 , with a mean of 5.8
(Table 1). Whereas mean expected heterozygosity was 0.721 , that observed was only 0.624 . The presence of null alleles was tested for using the program Micro-checker 2.2.3 (Van Oosterhout et al. 2004).

Linkage disequilibrium (tested using PopGene, version 1.32 - Yeh et al. 1998) was not detected at any of the loci. The nine microsatellites were also tested for in four distinct species of the genus Piper-P. attenuatum Buch.-Ham., $P$. hispidinervium C. DC., P. tuberculatum Jacq. and $P$. colubrinum Link. under the following PCR conditions: an initial cycle of $1 \mathrm{~min}$ at $94^{\circ} \mathrm{C}$ for denaturation, 30 cycles of $1 \mathrm{~min}$ at $94^{\circ} \mathrm{C}$ for denaturation, $1 \mathrm{~min}$ at $53^{\circ} \mathrm{C}, 1 \mathrm{~min}$ at $72^{\circ} \mathrm{C}$, and a final extension of $5 \mathrm{~min}$ at $72^{\circ} \mathrm{C}$. The results are shown in Table 2. The microsatellites developed and identified in this study will support the characterization of the Piper nigrum L. germplasm available in Brazil.

Acknowledgments The authors are grateful to the Brazilian National Science Research Council (CNPq) for its financial support.

\section{References}

Albuquerque FC, Duarte MLR, Benchimol RL, Endo T (2001) Resistência de piperaceas nativas da Amazônica à infecção causada por Nectria haematococca f. sp. piperis. Acta Amazôn 31(3):341-348

Billotte N, Lagoda PJL, Risterucci AM, Baurens C (1999) Microsatellite-enriched libraries: applied methodology for the development of SSR markers tropical crop. Fruits 54:277-288

Creste S, Tulmann Neto A (2001) Detection of single sequence repeat polymorphisms in denaturing polyacrylamide sequencing gels by silver staining. Plant Mol Biol Report 19:299-306

Doyle JJ, Doyle JL (1990) Isolation of plant DNA from fresh leaf tissue. Focus 12(1):13-15

Jaramillo MA, Manos PS (2001) Phylogeny and patterns of diversity in the genus Piper (Piperaceae). Amer J Bot 88:706-716

Johnson GK, Ganga G, Sandeep VR, Sasikumar B, Saji KV (2005) Identification of hybrids in black pepper (Piper nigrum L.) using male parent-specific RAPD markers. Curr Sci 88(2):216-218

Miller MP (1997) Tool for population genetic analysis (TFPGA) 1.3 A windows programs for the analysis of allozyme and molecular population genetic data. Computer software distributed by the author

Nair RR, Sasikumar B, Ravidran PN (1993) Polyploidy in a cultivar of black pepper (Piper nigrum L.) and its open pollinated progenies. The Japan Mendel Society. Cytologia 58:27-31

Nambiar PKV, Pillay VS, Sasikumaram S, Chandy KC (1978) Pepper research at Panniyur-a resume. J Plant Crops 6(1):4-11 
Quijano-Abril MA, Callejas-Posada R, Miranda-Esquivel DR (2006) Areas of endemism and distribution patterns for neotropical Piper species (Piperaceae). J Biogeogr 33:1266-1278

Rozen S, Skaletsky HJ (2000) Primer3 on the www for general users and for biologist programmer. In: Krawetz S, Misener S (eds) Bioinformatics methods and protocols: methods in molecular biology. Humana Press, Totowa, NJ, pp 365-386

Souza AP (2001) Biologia molecular aplicada ao melhoramento. In: Nass LL, Valois ACC, de Melo IS, Valadares-Ingles MS (eds) Recusos Genéticos \& Melhoramento-Plantas. Fundação, MT, pp 549-602
Temnykh S, DeClerck G, Lukashova A, Lipovich L, Catinhour S, McCouch S (2001) Computational and experimental analysis of microsatellites in rice (Oriza sativa L.): frequency, length variation, transposons association, and genetic marker potential. Genome 11:1441-1452

Van Oosterhout C, Hutchinson WF, Wills DP (2004) MICROCHECKER: software for identifying and correcting genotyping error in microsatellite data. Mol Ecol Notes 4:535-538

Yeh FC, Rong-Cai Y, Boyle T (1998) Popgene, version 1.31.. Center for International Forestry Research, University of Alberta, Edmonton, Alberta, Canadá 